UDC 721.012

JEL: M10, M19, O39

\section{Fadil Mušinović}

Phd,

Ljubljana School of Business,

Ljubljana, Slovenia

E-mail: fadil.musinovic@siol.net orcid.org/0000-0003-4729-7596

Received: October 11, 2021

Accepted: November 12, 2021

DOI: $10.31520 / 2616-7107 / 2021.5 .4-3$

(C) Economics. Ecology. Socium, 2021 CC BY-NC 4.0 license

\section{ORGANIZATIONAL MANAGEMENT WITH THE CRISIS OF THE COVID-19 PANDEMIC}

Introduction. During the Covid-19 pandemic, a crisis unmatched that will have significant negative consequences and encompass the social, economic and environmental environment and its consequences affect organizations in both the private and public sectors. The Covid-19 pandemic has a significant impact on the population and their lives, and therefore on their organizational effectiveness in overcoming the crisis. The crisis has caused a number of uncertainties and confusion related to workers' risks and the adoption of measures to overcome them. In the face of uncertainty, it is even more difficult to manage organizations that do not have properly developed, recognizable and competent crisis management and communication.

Aim and tasks. The purpose of the study was to highlight the pandemic-induced problems and to contribute to the adoption of measures related to the functioning of the organizations. Additionally, the aim was also to establish the connection between the introduction of new forms of work and the shortage of the staff. Main goal of this research was to analyse functioning of the crisis management in selected organizations during the Covid-19 pandemic.

Results. The results of the study conducted via an online questionnaire showed that crisis management and communication are adequately adopted in the organizations in question, but shortcomings were nevertheless disclosed. They are a consequence of the specificity of the crisis and the lack of knowledge of how to operate under such conditions. Participants of the survey estimated that the pandemic raised thus far investigated issues and that crisis management and communication in the organization was better trained to operate and take crisis measures in cases other than the epidemic.

Conclusions. The article proposes an analysis of the entire operation of management during the pandemic, a review of all organizational acts in the field of crisis management, their modernization, and additional training and education in crisis management by exchanging practices of other organizations. However, the state, as the holder of measures during the pandemic, must adopt appropriate legal acts, which will be the base for organizations in the economy and the public sector to take appropriate measures. Organizational management during the pandemic must be flexible, innovative and focused on a healthy work environment.

Keywords: Covid-19, crisis management, crisis communication, knowledge. 
УДК 721.012

JEL: M10, M19, O39

\section{Фаділь Мусінович}

Кандидат економічних наук, Школа бізнесу в Любляні, Любляна, Словенія

E-mail: fadil.musinovic@siol.net orcid.org/0000-0003-4729-7596

Отримано: Жовтень 11, 2021 Прийнято: Листопад 12, 2021

DOI: $10.31520 / 2616-7107 / 2021.5 .4-3$

(C) Економіка. Екологія. Соціум, 2021 CC BY-NC 4.0 ліцензія

\section{ОРГАНІЗАЦІЙНЕ УПРАВЛІННЯ В УМОВАХ КРИЗИ, СПРИЧИНЕНОЇ ПАНДЕМІЄЮ СОVID-19}

Вступ. В період пандемії Covid-19 була створена криза, яка матиме значні негативні наслідки та охоплює соціальне, економічне та екологічне середовище, i iii наслідки впливають на організації як в приватному, так i державному секторі. Пандемія Covid-19 має істотний вплив на населення та їхнє життя, а, отже, і на їхню організаційну ефективність в умовах подолання кризи. Криза спричинила виникнення невизначеності, пов'язаною із ризиками працівників та вжиттям заходів їх подолання. В умовах невизначеності ще важче управляти організаціям, які не мають належним чином розвиненого та компетентного антикризового управління та комунікації.

Мета i завдання. Метою дослідження було висвітлити проблеми, викликані пандемією, та сприяти прийняттю заходів з їх подолання щодо функціонування організацій. Крім того, метою було також встановити зв'язок між впровадженням нових форм роботи та дефіцитом кадрів. Основною метою цього дослідження було проаналізувати функціонування антикризового управління в окремих організаціях під час пандемії Covid19.

Результати. Результати дослідження, проведеного за допомогою онлайн-опитувальника, показали, що антикризове управління та комунікація адекватно прийняті в розглянутих організаціях, але недоліки, тим не менш, виявлені. Вони є наслідком специфіки кризи та незнання, як діяти в таких умовах. Учасники опитування визначили, що пандемія підняла досі не досліджені питання, i що кризове управління та комунікація в організації були краще підготовлені для роботи та вжиття кризових заходів у випадках, відмінних від епідемії.

Висновки. У статті пропонується аналіз усієї діяльності менеджменту під час пандемії, огляд усіх організаційних актів у сфері антикризового управління, їх модернізація та додаткове навчання та навчання 3 антикризового управління шляхом обміну практиками інших організацій. Проте держава, як суб'єкт заходів під час пандемії, має прийняти відповідні нормативно-правові акти, які стануть основою для вжиття відповідних заходів організаціями економіки та державного сектору. Організаційне управління під час пандемії має бути гнучким, інноваційним та орієнтованим на здорове робоче середовище.

Ключові слова: Covid-19, кризове управління, кризова комунікація, знання. 
Introduction. The Covid-19 pandemic is still here. Its dimension is immense. It has intervened in the personal, social, and economic environment. Its consequences are still immeasurable. The impact on the functioning of organizations is already showing. Its impact on humankind and their health has also been reflected in restriction of activities in public and economic organizations. In the public life, the greatest consequences are felt by the users of health services, as their entire operating is currently focused on preventing the spread of infections and treating patients affected by Covid-19.

On the other hand, the limited transport and global trade in goods and raw materials are impacting economic activities and their provision of appropriate materials needed to carry out their activities. The pandemic has created an environment of uncertainty and chaos regarding the adoption of measured related to the protection of employees and the organization itself from the spread of the pandemic. Ineffective management of the pandemic is also due to a lack of studies and information about the course and spread of the disease. Most organizations were very ill-prepared for this crisis. The role of crisis management and communication was initially left to their own discretion and solution-finding as our society has not yet encountered this type of the pandemic in this area.

The research shows that most measures taken in the analysed organizations were focused on the protection of employees and the prevention of virus transmission out of and into the organization. Whether their implementation was actually effective and whether the role of crisis management and communication contributed to this is evident from the research. Employees have recognized the role of these services and are aware of the crisis plans. However, the majority of respondents assessed that strategic crisis management and communication plans are adapted to the situation as a consequence of various economic and natural phenomena. The first part of the paper reviews the literature and concepts of crisis management and communication, the second part consists of the questionnaire findings, and the third part proposes possible future research.
Crisis management and crisis communication. The word crisis holds a negative connotation in both business and private environments. We associate it with uncertain, unknown results, bad experiences, and fears for the future. In a crisis situation, especially if we are not prepared for it (Covid-19), we no longer know what is right, where our path leads us, and how to continue with the established methods of work. But a crisis can also be the opposite of fear, it can be the disclosure of new paths and goals of successful action.

The meaning of the word crisis comes from the Greek word krisis or crinein. The dictionary of foreign terms defines it as a decision, a decisive moment, or a situation. The dictionary of Slovene literary language defines a crisis as a difficult, unfavourable situation. In the original meaning, the crisis was supposed to describe the turning point of sailboats in the competition, when one had to use all of their knowledge and skills to gain an advantage over their opponents. Just as the timely turnaround of the sailboat is what decides who wins and loses the competition, the crisis is an opportunity for the organization to gain a decisive competitive advantage or a better future [1].

Coombs [2] defines crisis as an unpredictable event, a major threat that can have a negative impact on the organization, industry, or stakeholders if the organizations handle it insufficiently. On the other hand, Dubrovski [3] doesn't treat crisis as a process, but rather as a state. A crisis is a short-term, unfavourable, undesirable, and a critical situation in a company, caused by both external and internal causes, that directly threatens the existence and further development of the company.

Crisis can also be defined as unplanned and undesirable processes that last for a limited time, which can be influenced only partially and which can end in a variety of ways [4].

A crisis is a significant, unplanned event with a potentially negative outcome. The event itself, and its consequences, can significantly affect the organization, its employees, products, services, financial state, and reputation. Crisis is unplanned, but not unexpected. Smart organizations know that one day they will be hit by a crisis, they just don't know when that will be. The crisis strikes suddenly, adding an element of surprise and unplannedness [5]. 
It is similarly described by Irvine as well, who claims it is a serious incident that affects human security, environmental products, or the organization's reputation. Such an incident is known to be addressed in a hostile manner by the media [6].

Crisis of an organization or a business is a specific and unexpected event that results in a threat to the uncertain overall operating of the organization. It prompts the organization to look for challenges to find and build tools for effective crisis management. Well-chosen instruments for identifying crisis significantly help the organization in preventive action and crisis management. Sensing a crisis is vital at the early stage of its emergence, while its dimensions are still narrow. The success of the crisis management is determined by the integration of knowledge and experience of different areas of crisis management [7]. The role of crisis communication is important for the successful operation of crisis management. Their mutual coordination and coherence ensure the successful resolution of crisis situations.

The state of the broad dimensions of the crisis denotes increased difficulty of controlling for the organization and requires the introduction of radical changes in the existing structure of management. A crisis situation causes negative conditions that can affect the lives of people, the financial security of the company, the existence of business partners and also endangers people in the organizational and business environment [8]. A crisis situation requires a relatively short time to elicit a response, represented by stress. Nevertheless, it is necessary to respond quickly, as it can otherwise lead to the expansion of its consequences and further escalation of the event. The way, in which the organization deals with the crisis situations, is what influences how it is defined. If the organization draws important lessons from the crisis, it can be used for growth and business success. Otherwise, it leads to chronic malfunctioning and disruption in the organizational process of ensuring its mission and the goals of the organization. A result of the ineffective crisis measures can be layoffs and poor financial results. To ensure a timely response to the crisis, it is important for the company to establish the crisis management, that will be able to deal with the crisis [9]. Crisis management does its job well if its tasks include avoidance or prevention of the crisis. All risks have the potential to escalate into a crisis, however, they can be detected early by collaborating with key public sectors, enabling the crisis management to address the problem before it grows too large [2].

The process of crisis management includes a wide range of company's or organization's activities, from preventive action ahead of the crisis, crisis management in the narrow sense, and all the way to the process of learning from the crisis [8]. There is no one way to solve the crisis. Every organization need to influence its behaviour during the crisis through pre-preparation, risk assessment, and planning and predicting future scenarios during and after the crisis.

The process of preparing for crisis conditions refers to the pre-crisis period - the preventive actions focused on the prospective learning. The crisis plan and its preparation are an important part of preventive actions. The crisis plan contains important components and steps to be taken in the case of a crisis.

During the process of preparing for a crisis situation, an important rate is played by crisis management and crisis communication. An adequate communication network and coordinated operation of the entire management (of which a part is also the crisis management) play a vital role in the preventive action, as well as in suitable and timely transfer of information on all stages of the organization, from the operational part to the top-level management.

Crisis manager or management can be formed within the company in the form of already employed staff who either temporarily take over a new function or are forced to connect their current work with new responsibilities, thus taking over fresh crisisrelated duties on top of their current tasks.

The title of crisis management is used for that type of strategic management that deals with extensive issues in the company that threaten its further existence and development. Unlike classic strategic management, crisis management has an increased share of operational (executive) decision-making and performance required by the alarming conditions [9]. 
We expect crisis management to possess a wide range of knowledge, outstanding characteristics, ideas, and experience. However, it can be that even a spectrum that large is not enough to cope with the crisis. According to Novak [4], many managers have a misconception about their preparedness for crisis and knowledge of emergency procedures, and it follows that the onset of the actual crisis shows a completely different picture with a lack of knowledge and time to deal with it effectively. Crisis communication (also communication in crisis) can be understood as a special adapted way of communicating in an extreme situation, where the newly formed issues and the interest of public force leaders to responds, while they want to establish a certain information balance.

Novak [4] defines such communication as a special area of public relations which includes anticipating of potential crisis events, preparing for them, resolving crises, and communicating with affected and other key publics of the organization, as well as assessing post-crisis measures. According to Končina \& Mirtič [10], every company strives to gain reputation to ensure a specific profile in the environment in which it is located. In time of crisis, a lack of reputation is a highly likely outcome, but it is up to the leaders to try to fix this potential loss. Especially the goals of rehabilitating the company and realistic possibilities for overcoming the crisis are information that should be provided to the key publics.

The main goal of crisis communication is to correct the current image of the organization by mitigating various responses that have emerged since the onset of the crisis [11].

Brändström \& Malešič [7] believe that credible crisis communication focuses on the relationship between available information, its timely and appropriate distribution, and sensing of the crisis along with measures to resolve it.

In theory, in addition to the concept of crisis communication, we also encounter a broader concept - communication of hazards, which is aimed at exchanging information between interested clients, especially about environmental hazards in order to manage or control them [12].

Crisis communication should not be taken too lightly. If anything, the leaders of the organizations should pay even more attention, research, and preparation to it. Stern \& Nohrstedt [13] emphasize the importance of information flow in times of crisis. It is necessary to aim for a balance between highquality information management and limited intervention to it [14]. Every situation that requires crisis communication is just as unique as the case of each individual crisis.

Covid-19 crisis in Slovenia. In December 2019, the Chinese province Wuhan detected an unusually high number of cases of pneumonia. After they excluded common respiratory infections as the cause, new coronavirus infections have been confirmed. The virus was named SARS-CoV-2, and the disease it causes Covid-19 (NIJZ, b. d. a).

The first case of infection in the Republic of Slovenia was detected on March 4, 2020. On that day, preventive measures began to be taken to control the spread of infectious disease worldwide. Due to the rapid spread of the disease worldwide, the World Health Organization (WHO) declared the coronavirus outbreak to be a pandemic on March 11, 2020, with health facilities seizing the provision of non-essential preventive health services. Slovenia officially declared an epidemic on March 12, 2020. With the appearance of the first coronavirus infections, epidemiological services began to actively seek close physical contacts between the infected population. In spite of active efforts to localize the sources of individual infections and to curb transmission among the population, the outbreak at the national level quickly reached worldwide proportions, leading the exponential spread of new infections to quickly become a serious threat to global public health. Preventive measures improved the situation in the summer of 2020, and the Government of the Republic of Slovenia repealed the state of epidemic on May 31,2020 , and began to gradually allow certain activities, given they follow certain restrictive measures. In September 2020, another increase of the number of confirmed cases was noticed, which was determined to be significantly higher than at the peak of the spring's wave of the epidemic. The state of the epidemic remained extensive until the end of April 2021, and surged again after August 2021, with the appearance of the Delta variant of Covid-19. 
In December 2020, the European Medicines Agency approved the first Covid-19 vaccine in the European Union, which launched mass vaccination of the population in order to control the infectious disease. With the aim of reducing the number of infected individuals and preventing the further spread of the disease throughout the population, the countries have actively started to implement the vaccination strategy, which should be achieved by vaccination of a sufficient percentage of the population. The current vaccination rate in the Republic of Slovenia is $54.2 \%$.

Aim and tasks. The main goal of this research was to analyse the functioning of crisis management in selected organizations during Covid-19. The purpose of the study was to highlight the problems arising from the pandemic and to contribute to the adoption of measures related to the operating of each organization. Additionally, the aim was to establish the connection between introduction of new forms of work and the shortage of staff.

Results. Empirical research was conducted on selected companies. Companies operate as a group in the area of energy source production and sales. The empirical research was conducted with the consent of the organizations using a questionnaire compiled on the basis of a study of relevant literature and personal experience. The survey was forwarded to all members of the organizations using the business email address. In this case, the survey is the most appropriate method as it also ensures the confidentiality of personal data and compliance with legal provisions. This led us to our research sample that helped answer the central research question; How recognized is the role of crisis management and crisis communication in organizational management of the Covid-19 measures. We were also interested in the shortcomings of crisis management and crisis communication. The survey questionnaire was sent to 186 e-mail addresses, of which 56 were not fully completed and 31 did not respond to the survey. In total, 99 people completed the survey questionnaire, which represents $53 \%$ of the primary sample which is taken account in analysing and processing the survey results. The sample constitutes of $27 \%$ women and $73 \%$ men, $17 \%$ had at least a university degree, $31 \%$ had a graduate degree, $16 \%$ had an undergraduate degree, $34 \%$ had a high school or vocational school degree, and $2 \%$ had less than vocational degree level of education. The majority $(79 \%)$ of participants are involved in the implementation of relevant activities in functional and operational management. Individual research results are described for all research questions asked in the survey, separately.

The first research question:

RQ1: Were you familiar with the work of crisis management and crisis communication in your organization prior to the Covid-19 epidemic? The question had two possible answers and possible expression of personal opinion. $51 \%$ of participants answered they have encountered these concepts previously. Following explanations were added to the answers:

- We were familiarized with these services in problem solving in production.

- We have a public relations department at work. If that is the same thing, then yes.

- In crisis situations, the leader convenes meetings where we look for solutions together.

- I don't interact with this, I am not the right one to address, I just do what is ordered.

- All measures are decided from above by the bosses.

RQ2: Where did you recognize the work of crisis management and crisis communication?

Table 1. Recognition of the work of crisis management and crisis communication.

\begin{tabular}{|l|l|l|l|}
\hline \multicolumn{1}{|c|}{ Statement } & F & M & SD \\
\hline $\begin{array}{l}\text { By a notice of the } \\
\text { supervisor }\end{array}$ & 99 & 4,80 & 0,64 \\
\hline $\begin{array}{l}\text { A different approach to } \\
\text { organization of work }\end{array}$ & 99 & 4,75 & 0,50 \\
\hline $\begin{array}{l}\text { Changes in the } \\
\text { organizational culture }\end{array}$ & 99 & 4,47 & 1,04 \\
\hline $\begin{array}{l}\text { Higher number of notices } \\
\text { on the implementation of } \\
\text { measures }\end{array}$ & 99 & 4,46 & 0,66 \\
\hline $\begin{array}{l}\text { Creating new ways of } \\
\text { working }\end{array}$ & 99 & 4,18 & 0,90 \\
\hline $\begin{array}{l}\text { Management decisions } \\
\text { are quick }\end{array}$ & 99 & 4.04 & 1,19 \\
\hline Legend: M - mean, SD - standard deviation \\
\hline
\end{tabular}


For the RQ2 participants responded to the posed statements and rated them via Likert scale, where 1 stood for "I strongly disagree" and 5, being the highest score, meaning "I strongly agree".

Table 1 shows that the role of crisis management and communication is best recognized through the notices of the supervisor $(\mathrm{M}=4.40)$ and a different approach to organization of work $(\mathrm{M}=4.75)$, which correlates with the statement that this role was recognized by designing new ways of working $(\mathrm{M}=4.18)$, as well. Consequently, it is estimated that the role of crisis management and communication also led to changes in the organizational culture $(\mathrm{M}=4.47)$ and that they received a higher number of notices than usual $(\mathrm{M}=4.46)$. The results are understandable as the period of Covid-19 infections proved to be uncertain, unclear, and cause a critical situation. Management makes decisions quickly $(\mathrm{M}=$ 4.04) as it is under pressure of the internal and external environment. It tries to manage the consequences of the crisis event and to prepare the company for a smooth continuation of business in the post-crisis period [4]. Lerbinger [15] calls this phase a crisis event and claims it is the most dramatic, volatile, and uncertain of all the phases. The decision-making time period is short, and actions have to be taken quickly and in an uncertain environment. During this period, management is trying to control and limit the consequences of the crisis. "In a crisis, the key iss the feasibility, impact, and speed of the effect of a solution" [16]. Important aspects are also flexibility and availability of the services [17].

RQ3: Were you aware of the crisis communication plan of your organization?

Table 2: Familiarity with the crisis communication plan

\begin{tabular}{|c|c|}
\hline Statement & F \\
\hline Yes & 56 \\
\hline No & 33 \\
\hline
\end{tabular}

The majority of participants (57\%) stated they were familiar with the crisis communication plan. In order to manage the crisis situation and increase the efficiency of crisis management, it is necessary to increase stakeholders' awareness with the crisis communication plan. The crisis communication plan makes it easier to divide tasks and at the same time ensures that everything necessary to eliminate the crisis is done. As a result, there is also no unnecessary disruption in the company or the communication team. In the event of a crisis, the list of necessary tasks and people to communicate with is essential [4]. According to Novak, the plan first has to be tested to see if it is adequately understandable and useful, which was not possible in the Covid-19 crisis, as it emerged and spread very quickly. As the time for action was short, there was no chance for simulating a crisis and the pre-prepared scenario.

RQ4: Which tasks were performed by the crisis management and communication?

Table 3: Tasks of the crisis management and communication.

\begin{tabular}{|l|c|c|}
\hline \multicolumn{1}{|c|}{ Statement } & Yes & No \\
\hline Weekly meetings & 47 & 52 \\
\hline $\begin{array}{l}\text { Increased communication } \\
\text { with employees }\end{array}$ & 68 & 21 \\
\hline $\begin{array}{l}\text { Creating safe zones in } \\
\text { case of infections }\end{array}$ & 75 & 24 \\
\hline $\begin{array}{l}\text { Consistent testing of } \\
\text { employees of }\end{array}$ & 86 & 13 \\
\hline $\begin{array}{l}\text { Separating the break time } \\
\text { into several sessions }\end{array}$ & 34 & 65 \\
\hline $\begin{array}{l}\text { Installation and abply } \\
\text { disinfectants and suppout } \\
\text { of protective equipment }\end{array}$ & 82 & 17 \\
\hline Alternating office work & 43 & 56 \\
\hline Work from home notices about & 26 & 44 \\
\hline $\begin{array}{l}\text { Timely noctions } \\
\text { infections } \\
\text { employees }\end{array}$ & 20 \\
\hline $\begin{array}{l}\text { Ban of socializing in } \\
\text { common areas }\end{array}$ & 73 \\
\hline
\end{tabular}

Based on the results from Table 3, we can see that participants agreed that most commonly noticed tasks of crisis management and crisis communication is the testing of employees $(87 \%)$, installation of disinfection devices and supply of protective equipment (83\%), and timely notifications of infections among employees $(80 \%)$. The least noticed activities were the ban of socializing in common areas $(26.3 \%)$, separating the break time into several 
sessions (34\%), and alternating office work $(43.4 \%)$. The inadequate role of alternating office work is also supported by the low effort of incorporate work from home (50.1\%), which is understandable given the organization of work of the organization in question.

RQ5: What are the most common problems you have encountered in your organization during the outbreak of the Covid19 pandemic?

Table 4: Most common problems during the epidemic

\begin{tabular}{|l|l|l|l|}
\hline Statement & F & M & SD \\
\hline Issues with staff & 99 & 3,20 & 1,40 \\
\hline $\begin{array}{l}\text { A large number of } \\
\text { employees were exhausted } \\
\text { due to the way of working }\end{array}$ & 99 & 3,83 & 1,13 \\
\hline $\begin{array}{l}\text { Due to the rapid spread of } \\
\text { infections among } \\
\text { employees, the control over } \\
\text { the virus was lost }\end{array}$ & 99 & 2,98 & 1,53 \\
\hline $\begin{array}{l}\text { Issues due to the lack of } \\
\text { personal safety equipment }\end{array}$ & 99 & 2,43 & 1,47 \\
\hline Lack of disinfectants & 99 & 2,03 & 1,37 \\
\hline $\begin{array}{l}\text { Due to the lack of rapid } \\
\text { test, testing of employees } \\
\text { was not possible }\end{array}$ & 99 & 1,62 & 1,13 \\
\hline $\begin{array}{l}\text { Most employees refuse to } \\
\text { be vaccinated }\end{array}$ & 99 & 2,74 & 1,29 \\
\hline $\begin{array}{l}\text { Problems with spreading } \\
\text { the virus due to contact } \\
\text { with an infected person }\end{array}$ & 99 & 2,78 & 1,28 \\
\hline Legend: M - mean, SD - standard deviation \\
\hline
\end{tabular}

Table 4 shows us that the most recognized problems are the exhaustion of employees due to their way of working $(\mathrm{M}=3.83 \%)$ and issues with staff $(\mathrm{M}=3.20 \%)$. The least reported problem was the lack of rapid tests that would disable the rapid testing of employees $(\mathrm{M}=$ $1.62 \%)$. Two interrelated problems, that are also the cause for the deficit of staff and subsequent exhaustion of the employees, are that most employees refuse to get vaccinated $(\mathrm{M}=2.72 \%)$ and problems with the spread of the virus due to the contact with an infected person $(\mathrm{M}=2.78 \%)$.
RQ6: Is there a link between staff shortage and the creation of new ways of working?

For this research question a null hypothesis was set:

H0: The lack of staff and the creation of new ways of working in the organization are not statistically related.

The correlation was assessed using the Spearman correlation coefficient.

\section{Table 5: Staff shortage and creation of new} way of working

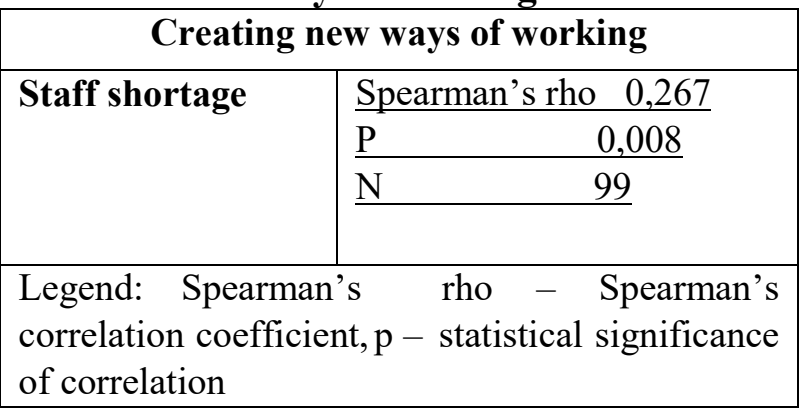

Table 5 shows the relationship between the shortage of staff and the creation of new ways of working. The results show that there is a (weak) statistically significant $(\mathrm{p}=0.008)$ association between the claims. The null hypothesis was rejected.

This claim was tested on the premise that the crisis could be the cause of the company's renewal. Renovation of the company is a consequence of the crisis, which requires the company to adopt new methods of work and strategic directions [5]. According to the results of the survey, the crisis situation of Covid-19 required the introduction of new methods of work in the organization in question.

Conclusions. The Covid-19 pandemic, which began its worldwide journey in early 2020, will be recorded as a specific crisis that has momentarily halted manufacture, trade, transport, tourism, and many other activities. It has caused a global downfall of the world economy. In March 2020, the Covid-19 virus spread to Slovenia as well. Companies were not prepared for such a crisis and lacked appropriate measures and skills. The survey conducted in June 2020 aimed to analyze the functioning of crisis management in selected organizations. 
The results presented in the article show that $51 \%$ of participants already encountered the concept of crisis management and crisis communication before.

The role of crisis management and communication is best recognized by a notice from a supervisor $(\mathrm{M}=4.40)$ and a different approach to the organization of work $(\mathrm{M}=4.75)$. The most important tasks were established to be consistent testing of employees $(87 \%)$, installation of disinfection devices and supply of protective equipment $(83 \%)$, and timely notifications of infections among employees.

The most recognized problems were exhaustion of the staff due to their way of working $(3.83 \%)$ and problems with staff $(\mathrm{M}=$ 3.20). Using the Spearman coefficient, we found that the results show a (weak) statistically significant $(p=0.008)$ correlation between these claims. It was also noted that the participants are familiar with the crisis plan and that the information regarding the consequences and ways of spreading the infection was sufficient.

This paper provides an insight into how the selected organizations had an already established crisis management and quickly responded to the crisis by purchasing appropriate protective equipment and establishing a crisis state.

\section{Future Research Directions.}

(1) Expanding the study to more organizations, comparison between public and private organizations;

(2) Measuring the level of exhaustion in staff resulting from the Covid-19 pandemic and related measures;

(3) Collecting and analysing studies on different approaches to taking measures to prevent the spread of the Covid-19 virus;

(4) Conducting research in the wider regional area and in the field of related work;

(5) Role of crisis management in taking action and whether there is a statistically significant correlation between the tasks of crisis and security management;

(6) The issue of experiencing stress in the workplace during Covid-19 remains open;

There is a lack of proper research on the internet that connects and establishes connections between individual services of an organization during the epidemic, with researchers paying too little attention to choosing the appropriate methodology. There is also a lack of research in Slovenia that would investigate the effects of the measures taken, and based on the findings, propose concrete solutions for the future. They are required; the virus is changing its shape. 


\section{REFERENCES}

1. Irvine, R. B. (1997): What is a crisis anyway. Communication World.

2. Coombs, T. (2012.), Ongoing Crisis Communications, Los Angeles: Sage Publications

3. Dubrovski, D. (2004). Krizni management in prenova podjetja. Koper: Fakulteta za management.

4. Novak, B, (2000). Krizno komuniciranje in upravljanje nevarnosti. Priročnik za krizne odnose z javnostmi v praksi. Gospodarski vestnik, Zbirka Manager, Ljubljana

5. Coombs, W. Timothy (2001). Ongoing crisis communication: Planing, managin, and responding. Sage Publications, California

6. Dubrovski, D. (2011). Razsežnosti kriznega managementa. Celje: Mednarodna fakulteta za družbene in poslovne študije.

7. Brändström, A., \& Malešič, M. (2004). Crisis management in Slovenia: comparative perspectives. Stockholm: Swedish National Defence College.

8. $\quad$ Osmanagić-Bedenik, N. (2003.), Kriza kao šansa. Zagreb: Školska knjiga

9. Dubrovski, Dr. (1998): Krizni management in prestrukturiranje podjetja: Visoka šola za management $\mathrm{v}$ Kopru

10. Končina, M., \& Mirtič, K. (1999). Kako rešiti podjetje iz krize. Ljubljana: Gospodarski vestnik.

11. Tafra-Vlahović, M. (2011.), Upravljanje krizom: procjene, planovi, komunikacija. Zaprešić: Visoka škola za poslovanje i upravljanje „Baltazar Adam Krčelić““

12. Malešič, M., Bašić-Hrvatin, S. \&Polič, M. (2006). Komuniciranje v krizi. Ljubljana: Fakulteta za družbene vede.

13. Nohrstedt, D., \& Stern, E. (1999). Conclusion: Patterns and Problems in Estonian Crisis Management. Crisis Management in Estonia: Case Studies and Comparative Perspectives, 3, 294315.

14. Koval, V., Polyezhayev, Y., \& Bezkhlibna, A. (2018). Communicative competences in enhancing of regional competitiveness in the labour market. Baltic Journal of Economic Studies, 4(5), 105-113. https://doi.org/10.30525/2256-0742/2018-4-5-105-113

15. Lerbinger, O. (1997) The crisis manager: facing risk and responsibility. Lawrence Erlbaum Associates, New Jersey.

16. Simon, H. (2009). Kriza - kako uspešno poslovati v spremenjenih razmerah: 33 učinkovitih rešitev za vašo gospodarsko družbo. Planet GV, Ljubljana.

17. Kajzer, S̆. (1998). Krizni management. Naše gospodarstvo. 